\title{
Peculiarities of simulation of the additive process of forming of 3D products from steel 09G2S
}

\author{
Specyfika symulacji procesu addytywnego formowania \\ produktów 3D ze stali 09G2S
}

\begin{abstract}
The results of modeling of thermal fields, stresses, deformations and displacements in formation of an additive structure of $09 \mathrm{G} 2 \mathrm{~S}$ steel on a substrate are presented. An interdisciplinary research computational package COMSOL Multiphysics was used for computer modeling. Effect of the temperature on physicochemical parameters of steel was taken into account in the work. The results for modeling were obtained using Gleeble 3800 a complex for simulation of thermal deformation state of welding thermal cycle. Some physical-thermal properties of 09G2S steel were calculated using JmatPro 6.0 software package. Carried investigation showed that the highest level of residual stresses and deformations in additive deposition of 09G2S steel layers on the substrate is reached at the boundary of the first layer and substrate and makes 280-320 MPa. Stresses between the layers of deposited metal are significantly lower (to $50 \mathrm{MPa}$ ). It is determined that the increase of the number of deposited layers provokes nonlinear rise of a level of stress at the additive layer/substrate boundary and does not depend on the number of deposited layers in time. In additive manufacturing process, preheating to at least $300 \div 320{ }^{\circ} \mathrm{C}$ temperature should be used to prevent noticeable deformation of the substrate. Developed software can be used for mathematical modeling of additive process of formation of steel,

\section{Streszczenie}

Przedstawiono wyniki modelowania pól termicznych, naprężeń, odkształceń i przemieszczeń przy formowaniu konstrukcji addytywnej ze stali 09G2S na podkładce. Dla dokonanego modelowania komputerowego wykorzystano pakiet dla międzydyscyplinarnych badań COMSOL Multiphysics. W pracy uwzględniono wpływ temperatury na parametry fizykochemiczne stali. Wyniki dla modelowania otrzymano z wykorzystaniem kompleksu imitowania stanu termo-odkształceniowego cyklu termicznego spawania Gleeble 3800. Właściwości fizyko-termiczne stali 09G2S obliczono za pomocą pakietu JmatPro 6.0. Przeprowadzone badania świadczą, że przy nanoszeniu addytywnym warstw stali 09G2S na podkład największy poziom naprężeń resztkowych i odkształceń osiąga się na granicy pierwszej warstwy i podkładki i stanowi $280 \div 320 \mathrm{MPa}$. Naprężenia miedzy warstwami metalu napawanego są znacznie niższe (do $50 \mathrm{MPa}$ ). Ustalono, że ze wzrostem ilości warstw naniesionych poziom naprężeń na granice warstwa addytywna/podkład wzrasta nieliniowo i z czasem nie zależy od ilości warstw nanoszonych. Przy procesie addytywnym dla zapobiegania odkształcenia podkładu należy stosować poprzednie nagrzewanie do temperatur $300 \div 320{ }^{\circ} \mathrm{C}$. Te programy mogą być stosowane dla modelowania matematycznego procesu formowania konstrukcji ze stali i stopów aluminiowych.
\end{abstract} titanium and aluminum alloys structures. Ref. 12, Figures 7.

Keywords: additive manufacturing; modeling; steels; deposition; stresses; microstructure
Słowa kluczowe: produkcja addytywna; modelowanie; stale; napawanie; naprężenia; mikrostruktura

\section{Introduction}

Additive technology is a new high-performance metallurgical method for structures development in current engineering $[1 \div 3]$. Today additive technologies (additive manufacturing) or technologies for layer-by-layer deposition material by means of surfacing, spraying or synthesis are the most dynamically developing direction of "digital" production. They allow significantly accelerating research and experimental developments and ensuring fast production of new finished products.

There are number of technologies that can be conditionally called additive ones. All these technologies combine a process of part formation by adding new material (from English to add) in contrast to traditional technologies, where production of a part takes place by "excess" material removal.

Prof. dr hab. inż. Gieorgij M. Grigorenko, dr hab. inż. Walery A. Kostin, dr Irena A. Mossokovskaya - Electric Welding Institute of the NAS of Ukraine.

Autor korespondencyjny/Corresponding author: valerykkos@gmail.com 
A term additive manufacturing (AM) is commonly referred to a group of technological methods for rapid design and development of the products, which allows producing solid, volumetric products of various materials using three -dimensional computer model [4]. ASTM F2792-12A standard defines the AM term as "a method of materials joining, at which production of an object takes place layer-by-layer on a given digital 3D model." The first additive manufacturing methods appeared in the early 80 of the last century. Mainly, they were focused on manufacture of products of polymer materials, plastics and rubbers. At present, these methods have found a successful commercial application in metallurgy, machine building, architecture, space and aerospace engineering, medicine, and military industry [5]. In addition to the traditional methods of additive manufacturing, the methods using metallic materials and alloys as consumables have been rapidly developing.

AM methods have a series of advantages in comparison with classical production methods, namely:

- Possibility of complete automation of the product manufacturing process (including the stage of digital 3D model development). This reduces time necessary for product manufacture and generally decreases the total production time.

- High competitiveness of AM methods for manufacture of products from expensive titanium and nickel alloys and alloys of refractory materials due to low material loss factor. This advantage is especially important in aerospace industry in which manufacture of parts is often associated with high coefficient of material consumption.

The additive manufacturing methods have some disadvanatages. Additive methods have a relatively low productivity, require presence of a vacuum chamber or chamber with protective atmosphere, high residual stresses and strains are formed during part deposition and a relatively low manufacturing accuracy and typical surface ribbing or "layering" are present.

European standard ASTM F2792 proposes to divide the methods of additive manufacturing of metallic products on a principle of product formation used by them.

The following are referred to the methods based on fusion/sintering of powder substrate, i.e. selective laser sintering (SLS); selective laser melting (SLM) and electron beam melting (EBM).

The methods based on the injection of a binder on a powder substrate include powder bed and inkjet 3D printing (3DP).

The methods based on continuous fusion of metallic wire with concentrated energy sources cover laser engineered net shaping (LENS); wire feed laser beam (WFLB); electron beam freeform fabrication (EBF3); wire and arc additive manufacturing (WAAM).

All methods of additive manufacturing based on fusion, sintering or bonding of powders can be conditionally considered as a variant of the same process. The difference between these methods lies only in a method of joining for metallic powder particles.

Additive manufacturing methods based on fusion or sintering of metallic powder use the highly concentrated energy sources, namely laser or electron beam as a heating device. The laser or electron beam directly affects a layer of powder substrate provoking its selective fusion. Displacement in a vertical direction results in layer-by-layer deposition of a solid product.

Application of selective laser sintering method allows manufacturing products of various metallic composition and physical-metallurgical properties.
AM methods, based on fusion of metallic powder materials, use a protective chamber with vacuum or protective atmosphere.

Currently AM methods, using powder as a consumable, are more widely used in comparison with the methods applying metal wire.

Employing metallic powder in additive manufacturing provides a number of advantages that are typical for powder metallurgy methods. For example, it allows manufacture of the products from various powder metallic compositions.

Productivity of AM powder methods is quite low and makes several grams per minute. This significantly limits the possibilities of industrial application of these methods in manufacture of large-size products. Application of the protective chamber and peculiarities of work with powder materials obviously reduce the efficiency of AM powder methods.

AM methods, using wire as a consumable, have higher efficiency than AM powder methods. They have higher energy efficiency, high material utilization rate, provide larger mass productivity. All this justifies application of additive methods for manufacture of large-size products.

Microstructure of the samples made by different additive methods are very similar [6]. Nevertheless, higher porosity of metal of the part produced by powder methods should be noted.

AM methods depending on the type of used concentrated energy source are divided on laser, electron beam, electric arc and arc.

AM laser and electron beam methods differ by increased accuracy of product manufacture. In comparison, with laser and electron beam deposition, arc deposition of metallic wires has higher efficiency of consumables application. Nevertheless, all AM methods with wire have a series of common features, namely high residual stresses and strains, substrate overheating and relatively low accuracy of part manufacture.

Application of additive methods from point of view of formation of the structure of deposited metal allows forming more homogeneous and disperse metal structure in comparison with the traditional cast one. Absence of chemical inhomogeneity, dendrite and zonal liquation is related with small size of liquid pool and high solidification rate of deposited metal $[7,8]$.

Appropriate deposition method, type of used material, preliminary developed 3D mathematical model is necessary for optimum properties of additive structures. Process of additive deposition requires control of forming temperature fields, stresses and strains in the deposited layers in order to provide formation of necessary product shape, its structural state and mechanical properties.

At the same time, direct determination of these parameters during deposition is a rather difficult practical task. Modern methods of analysis of metallurgical production, i.e. computer modeling of 3D additive processes can be useful for solution of this problem.

At the same time, number of works dedicated to computer modeling of additive processes, kinetics of temperature changes, peculiarities of formation of stress-strain state in the additive models are still insignificant.

High residual stresses and deformations appearing in deposition of metallic wire should also be considered. They can significantly reduce performance characteristics of the products.

Aim of the work lies in optimizing the parameters of additive process of layer-by-layer formation of 09G2S steel billet based on calculation of temperature fields, stresses and strains forming in deposition. 


\section{Material and research method}

Well-known steel 09G2S was taken as a material for computer modeling. This steel was selected due to the need to take into account during the modeling a dependence of steel properties (density, thermal conductivity, heat capacity, thermal expansion coefficient) on temperature as well as absence of structural transformations in a temperaturetime cooling interval in this steel.

The latter is important due to the fact that in this case modeling requires solution of only temperature and deformation problems. This significantly simplifies calculation model and reduces calculation time.

One of the important problems, which appear in modeling of new processes using new materials and alloys, is the absence of initial experimental data on dependence of materials properties on temperatures, cooling rates, and loads. Public access to information about new materials properties is rather limited.

Temperature dependence of properties of modeled steel 09G2S was experimentally determined applying Gleeble 3800 complex simulating thermal deformation state metal in welding thermal cycle under tension.

Effect of heating temperature on a coefficient of thermal expansion of 09G2CS steel was studied using Gleeble 3800 complex for simulation of metal thermal deformation state. The complex is equipped with a fast dilatometer.

The investigations were carried out on cylindrical specimens of $6 \mathrm{~mm}$ diameter and $80 \mathrm{~mm}$ length, made of rolled $09 \mathrm{G} 2 \mathrm{~S}$ steel of $20 \mathrm{~mm}$ thickness. In accordance with the procedure developed at the E. O. Paton Electric Welding Institute, the samples were heated in a vacuum chamber to $1170^{\circ} \mathrm{C}$ temperature following a set program and held at this temperature for 5 minutes, and then cooled at different rates. The cooling rates in a temperature range of $500 \div 800{ }^{\circ} \mathrm{C}$ made $0.1 ; 1 ; 5 ; 10 ; 15 ; 20 ; 25^{\circ} \mathrm{C} / \mathrm{s}$. The choice of such cooling rates allowed sufficiently accurate reproduction of thermal cycle cooling parameters during electric arc deposition (thermal and time).

The thermal system of Gleeble 3800 complex allows performance of high-precision dilatometric measurements of linear expansion coefficients, phase transformation temperatures and calculation of number of forming phases. Experimental data were processed interactively employing Origin 9.0 application.

The other physico-thermal properties of steel 09G2S necessary for numerical simulation were calculated using JmatPro 6.0 software package developed for modeling steels and alloys properties. The JMatPro software by Sente Software (Great Britain) is supposed to be the leader in the field of computer forecasting of steels and alloys properties necessary for analysis of the processes of metal treatment by pressure, heat treatment, cutting, casting processes, strength calculations of structure etc. The main input data necessary from a user of JMatPro to obtain the physical and thermal properties of the material are chemical composition of the material and index characterizing its grain size in the initial state.

Figure 1 shows the effect of heating temperature on physical thermal properties of 09G2S steel.

The interdisciplinary research calculation package COMSOL Multiphysics $[9,10]$ was used for computer modeling. It allows combining the problems of diffusion, heat and mass transfer, hydrodynamics, mechanics of deformed solid body into one interrelated task.
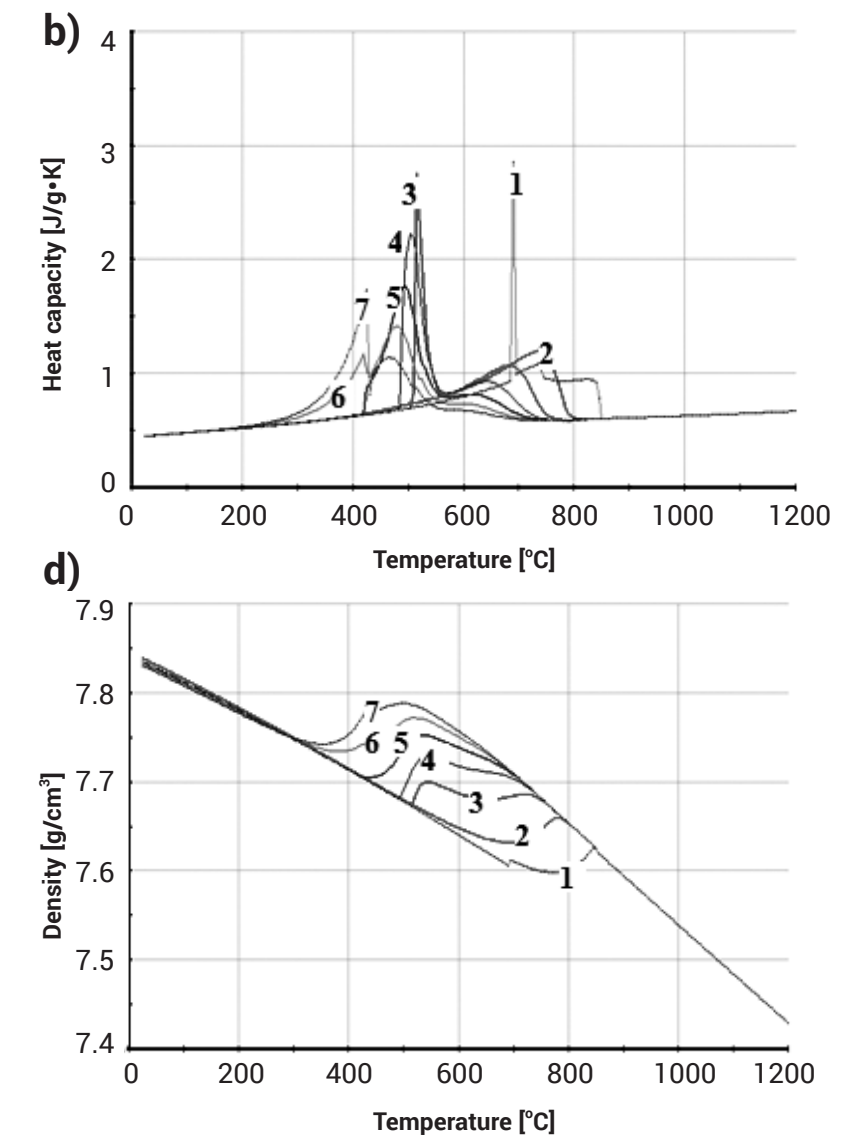
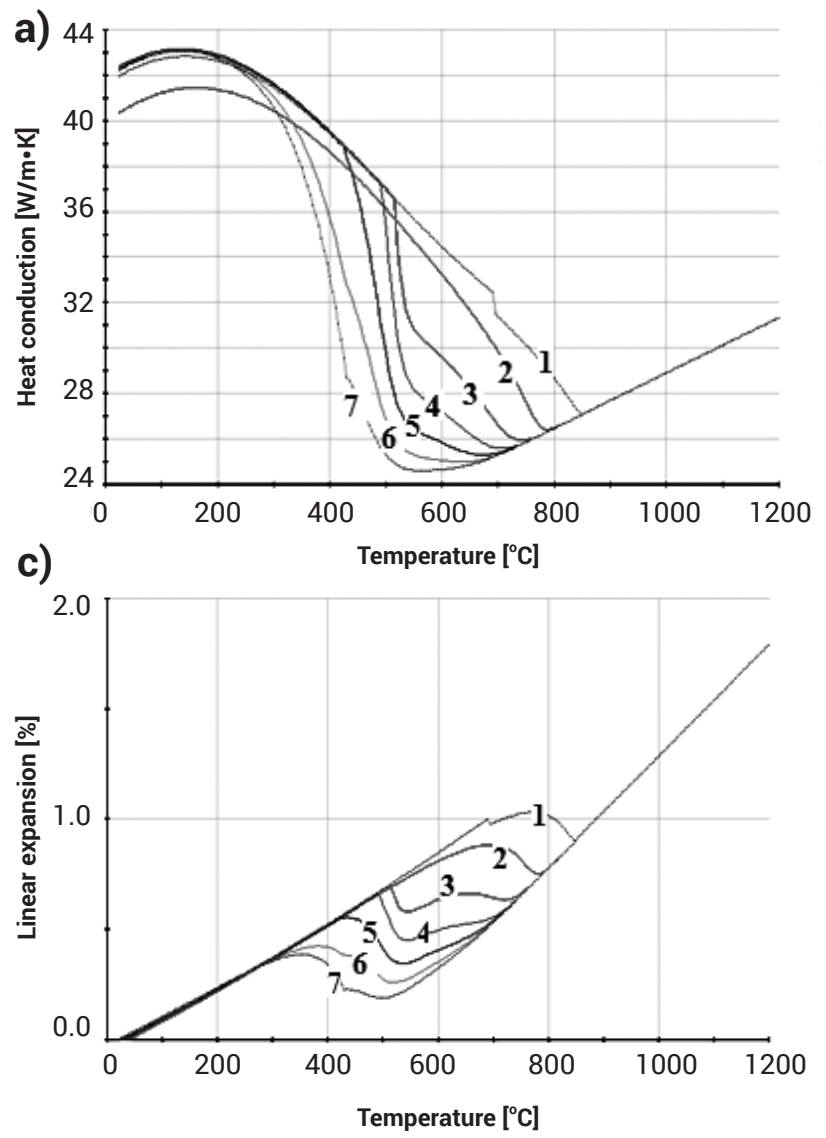

Fig. 1. Effect of heating temperature on physical thermal properties of $09 \mathrm{G} 2 \mathrm{~S}$ steel: a) thermal conductivity $[\mathrm{W} /(\mathrm{m} \cdot \mathrm{K})], \mathrm{b}) \mathrm{heat}$ capacity $[\mathrm{J} /$ $(\mathrm{r} \cdot \mathrm{K})]$, c) temperature linear expansion $[\%], \mathrm{d})$ density $\left[\mathrm{g} / \mathrm{cm}^{3}\right]$ depending on the cooling rate: $1-0.1{ }^{\circ} \mathrm{C} / \mathrm{s} ; 2-1{ }^{\circ} \mathrm{C} / \mathrm{s} ; 3-5^{\circ} \mathrm{C} / \mathrm{s} ; 4-10^{\circ} \mathrm{C} / \mathrm{s}$; $5-15^{\circ} \mathrm{C} / \mathrm{s} ; 6-20^{\circ} \mathrm{C} / \mathrm{s} ; 7-25^{\circ} \mathrm{C} / \mathrm{s}$

Rys. 1. Wpływ temperatury ogrzewania na fizyczne właściwości termiczne stali 09G2S: a) przewodność cieplna [W/(m•K)], b) pojemność cieplna $[\mathrm{J} /(\mathrm{r} \cdot \mathrm{K})], \mathrm{c})$ rozszerzalność liniowa temperatury $[\%]$, d) gęstość $\left[\mathrm{g} / \mathrm{cm}^{3}\right]$ w zależności od szybkości chłodzenia: $1-0.1^{\circ} \mathrm{C} / \mathrm{s} ; 2-1^{\circ} \mathrm{C} / \mathrm{s}$; $3-5^{\circ} \mathrm{C} / \mathrm{s} ; 4-10{ }^{\circ} \mathrm{C} / \mathrm{s} ; 5-15^{\circ} \mathrm{C} / \mathrm{s} ; 6-20^{\circ} \mathrm{C} / \mathrm{s} ; 7-25^{\circ} \mathrm{C} / \mathrm{s}$ 
The COMSOL Multiphysics ${ }^{\circledR}$ package includes a set of preliminary configured user's interfaces, modules and modeling tools that significantly facilitate the process of development of mathematical model and setting a 3D model of calculation area.

Physical model of the additive process for layer deposition was built on a number of assumptions. Deposition geometry consists of layers of $09 \mathrm{G} 2 \mathrm{~S}$ steel of $1.0 \mathrm{~mm}$ thickness, $3.0 \mathrm{~mm}$ width and $28 \mathrm{~mm}$ length.

Number of deposited layers was determined by the condition, at which deposition of subsequent layers of material does not affect the level of stresses on layer/substrate boundary, i.e. shifts to "shelf type" stationary mode. It was assumed based on the experiment results, that the droplets of molten metal of $09 \mathrm{G} 2 \mathrm{~S}$ steel in the initial moment of time have temperature equal to metal melting temperature $T_{m}=1823 \mathrm{~K}$. The layers were deposited to a substrate of St3 grade steel. To simplify model structure geometry it was assumed that the drops are the geometry elements of regular shape in form of parallelepipeds of $1 \times 3 \times 1 \mathrm{~mm}$ size. The properties of initial material of additive layers are homogeneous and depend on temperature (density, heat capacity, coefficient of thermal expansion, Fig. 1). Movement of liquid phase was not taken into account. The work assumed a limitation that arc heating source or laser does not heat the substrate.

A model of linear elastic material is adopted in the calculations. Stresses and strains in the model appear as a result of development of shrinkage effects due to decrease of material volume in cooling. Heat transfer in the layers is carried out by heat conduction, convection and radiation into environment with Text temperature.

Kinetics of change of temperature and deformation fields in this case of additive layers deposition has mainly a 3D nature, which does not allow limiting investigation by only 2D model.

The mathematical model for deposition of the additive layers can be described by a number of mathematical equations.

Solution of 3D non-stationary heat conduction equation was used for numerical analysis of kinetics of change of temperature fields in the deposited layers:

$$
\rho C_{p}\left(\frac{\partial T}{\partial t}+u \cdot \nabla T\right)=\nabla \cdot[k(T) \nabla T]
$$

where: $\rho C_{p}$ is the specific heat capacity and $k$ is the material heat conduction.

The boundary conditions, necessary for solution of equation (1), are determined by balance of heat supply and sink from the surface of deposited part. Thus, heat sink in the area of contact of the deposited part with the substrate can be described by the Newton's law, while thermal radiation on a free surface follows the Stefan-Boltzmann law. Additional heating from the heating source should be taken into account if it is sufficiently close to the edge of part being deposited.

The boundary conditions for solution of heat conduction equation (1) have the following form:

$$
k(T) \frac{\partial T}{\partial n}=\left\{\begin{array}{l}
h\left(T-T_{\text {ext }}\right) \\
\text { in zone of contact with substrate } \\
\varepsilon \sigma_{o}\left(T^{4}-T_{\text {ext }}^{4}\right)-q \\
\text { on free surfaces }
\end{array}\right.
$$

where: $n$ is the normal vector to the surface, $h=10\left[\mathrm{~W} / \mathrm{m}^{2} \cdot \mathrm{K}\right]$ is the heat transfer coefficient [11], $\varepsilon=0.8$ is the emissivity factor of the material, $\sigma_{o}$ is the Stefan-Boltzmann constant, $T_{\text {ext }}=293[\mathrm{~K}]$ is the ambient temperature, $q$ is the heat flow from the heat source. At this stage of investigations, this flow was not taken into account $\left(q=0 \mathrm{~W} / \mathrm{m}^{2}\right)$. In further works it is supposed to consider this additional heat flow and use as laser, electron beam and electric arc heat sources, which are characterized by different spatial distribution of thermal power.

Relationship between the components of stress and strain tensors (Hooke's law in tensor form) and time displacements can be written in the following form:

$$
\begin{aligned}
& \rho \frac{\partial^{2} u}{\partial t^{2}}=\nabla \cdot(F * S)+f_{v o l} \\
& S=C: E_{e l}
\end{aligned}
$$

where: $u$ is the displacement, $F$ is the strain gradient, $S$ is the Kirchhoff stress tensor, $E_{e l}$ is the elastic strain tensor, $C$ is the elastic modulus tensor, $f_{\text {vol }}$ is the volume forces related with thermal expansion of material based on thermo-elasticity equations: for small deformations: $E_{t h}=a\left(T-T_{\text {out }}\right)$; for large deformations: $J_{\text {th }}=\left(1+a\left(T-T_{\text {out }}\right)\right)^{3}$, where $a$ is the coefficient of thermal expansion.

Deposition of layers in this work was considered as a successive process of droplets-"cubes" deposition. The actual shape of the droplets and effect of surface tension forces on its surface have not been considered yet. Solution of the differential equations was carried out using finite element method (MCE) by constructing an inhomogeneous adaptive mesh and specifying the Lagrange interpolation coefficient of the second order in each cell of the mesh. The maximum size of mesh elements was $0.1 \mathrm{~mm}$. An algebraic system of equations obtained by discretization of the ordinary differential equations was calculated in the MUMPS solver (time dependent solver), which is an integral part of the COMSOL Multiphysics package.

\section{Modeling results}

The results of numerical experiments were used for calculation of temperature (Fig. 2), stresses (Fig. 3a), deformations and displacements (Fig. $3 b$ ) field at each moment of time at subsequent deposition of additive layers on the substrate.

The results of solution of a temperature problem (Fig. 2) show that kinetics of temperature field change has a three -dimensional nature, however, temperature in a deposited thin wall is sufficiently uniformly distributed in transverse direction.

One of the important tasks, solved at this stage, was investigation of the possibility to get a stationary temperature field and stress field in beads subsequent deposition of.

Solution of this problem allows optimizing the technological process as well as ensuring the uniformity of structural state of deposited additive layers along the whole product section and, consequently, provide uniformity of mechanical and service properties.

Analysis of kinetics of temperature fields change (Fig. 2) showed that the deposited layer significantly effects mainly previous layer, which is related to small size of layer thickness and its rapid cooling.

Analysis of the results of modeling the additive process for deposition of steel 09G2S layers showed that the level of stresses at additive layer/substrate boundary varies from 280 to $320 \mathrm{MPa}$. Stresses are virtually absent (do not exceed $50 \mathrm{MPa}$ ) at the boundaries of additive layers being deposited and, therefore, the model of linear elastic material used in the calculations provides sufficiently reliable results. 
a)

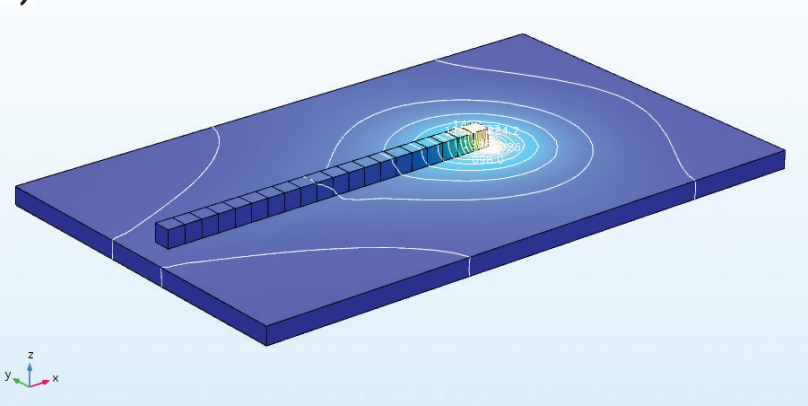

c)

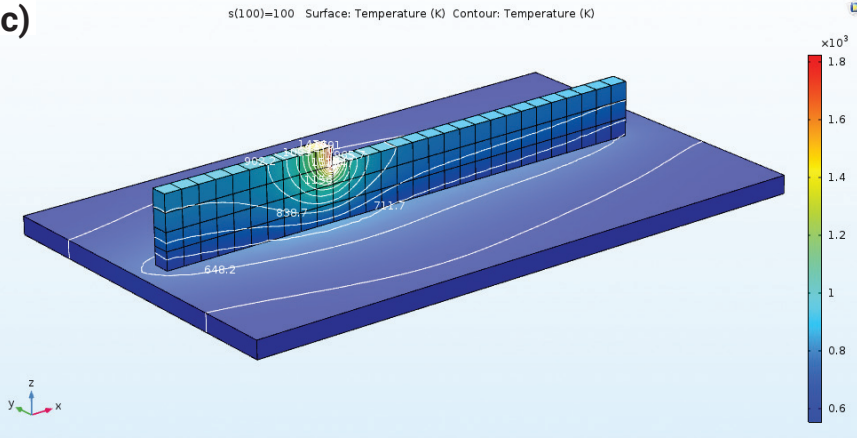

b)

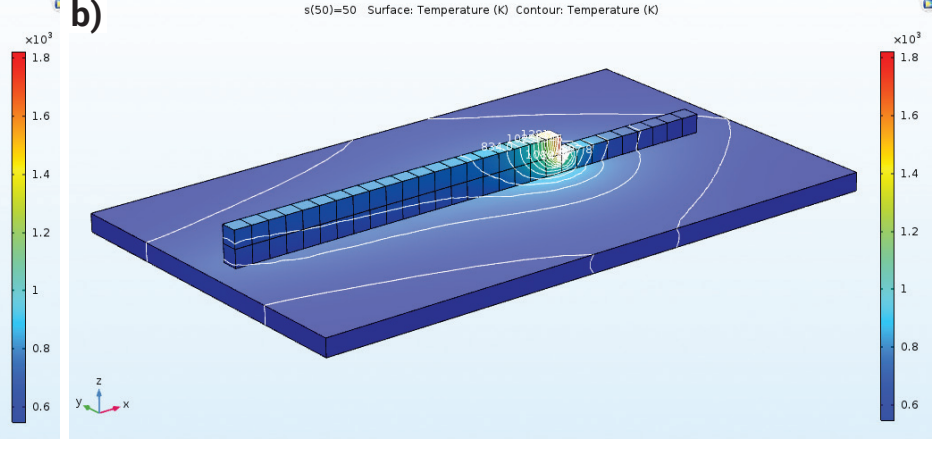

${ }^{a}$ d)

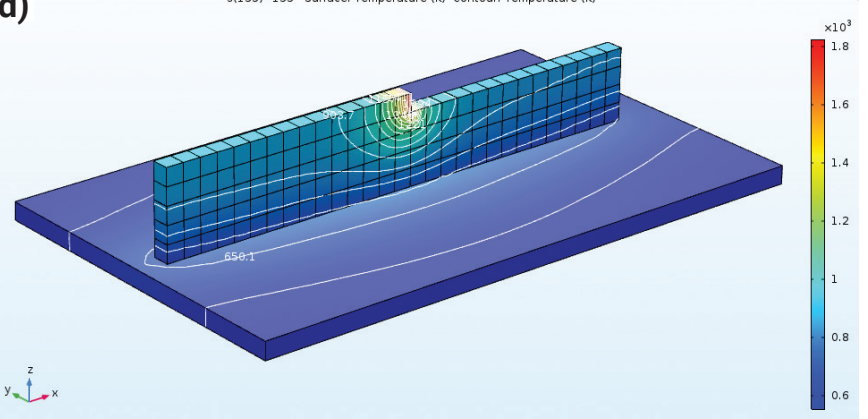

e)

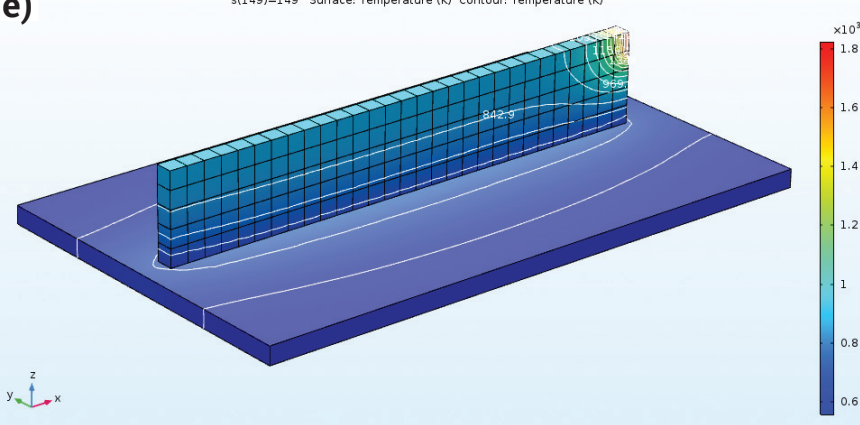

Fig. 2. Calculation of kinetic changes of temperature fields in deposition of 09G2S steel on substrate in time: a) $20 \mathrm{~s}, \mathrm{~b}) 50 \mathrm{~s}, \mathrm{c}) 100 \mathrm{~s}$, d) $135 \mathrm{~s}, \mathrm{e}) 149 \mathrm{~s}$

Rys. 2. Obliczenia kinetycznych zmian pól temperatur przy naniesieniu stali 09G2S na podkład w czasie: a) $20 \mathrm{~s}$, b) $50 \mathrm{~s}, \mathrm{c}) 100 \mathrm{~s}$, d) $135 \mathrm{~s}$, e) $149 \mathrm{~s}$

a)

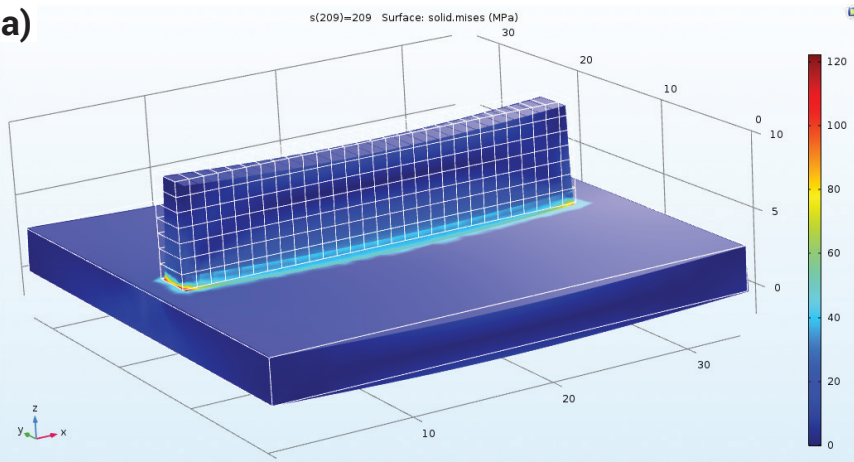

b)

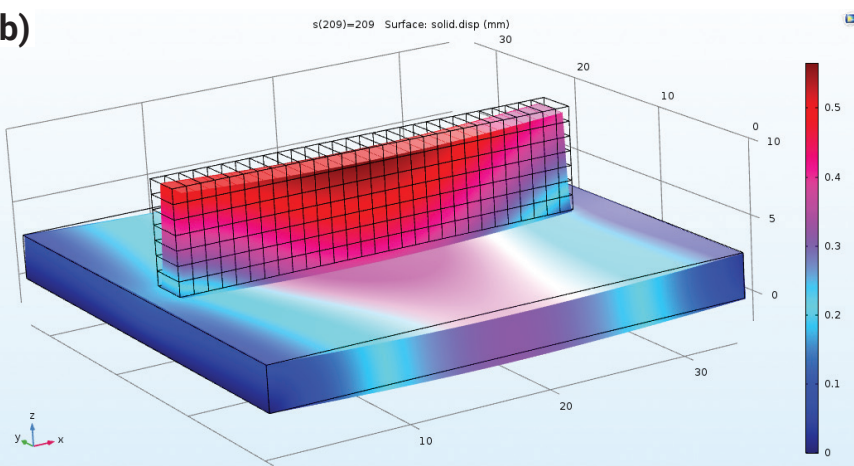

Fig. 3. Calculation of stress values (a) and total displacements (b) in deposition of 7 additive layers of steel $09 \mathrm{G} 2 \mathrm{~S}$

Rys. 3. Obliczenia wartości naprężeń (a) i całkowitych przemieszczeń (b) przy naniesieniu 7 warstw addytywnych stali 09G2S

Analysis of effect of number of deposited layers on stress-strain level at layer/substrate boundary showed (Fig. 4) that increase of layers number promotes gradual rise of the parameters, however increment value for stresses and displacements gradually decreases with a rise number of layers.

In course of simulation, it was determined that no increase of stresses at additive wall/substrate boundary takes place in $50 \div 60 \mathrm{sec}$ from the beginning of layer deposition process, i.e. after third layer deposition. This allows limiting calculation of the first $3 \div 4$ layers and significantly reduces resource intensity of numerical calculations. Nevertheless, obtained results describe the additive deposition process with sufficient accuracy and reliability.
This work provided a model of part fixture, at which both ends of the plate were fixed. Such type of fixture results in the fact that layer-by-layer deposition provokes residual bending deformations in longitudinal direction of the product as a result of development of shrinkage phenomena reducing material volume in cooling. The calculations show a noticeable deformation of the substrate during successive deposition of the layers. The maximum deflection in the middle part of substrate was $0.32 \mathrm{~mm}$ (Fig. 4b)

Evidently, preheating of the substrate or its preliminary bending should be used to prevent a noticeable deformation of the structure. The calculations show (curves 3, 4 and 5, Fig. 4b) that the higher preheating temperature of the substrate, the lower is the stresses and bending at layer/substrate boundary. 

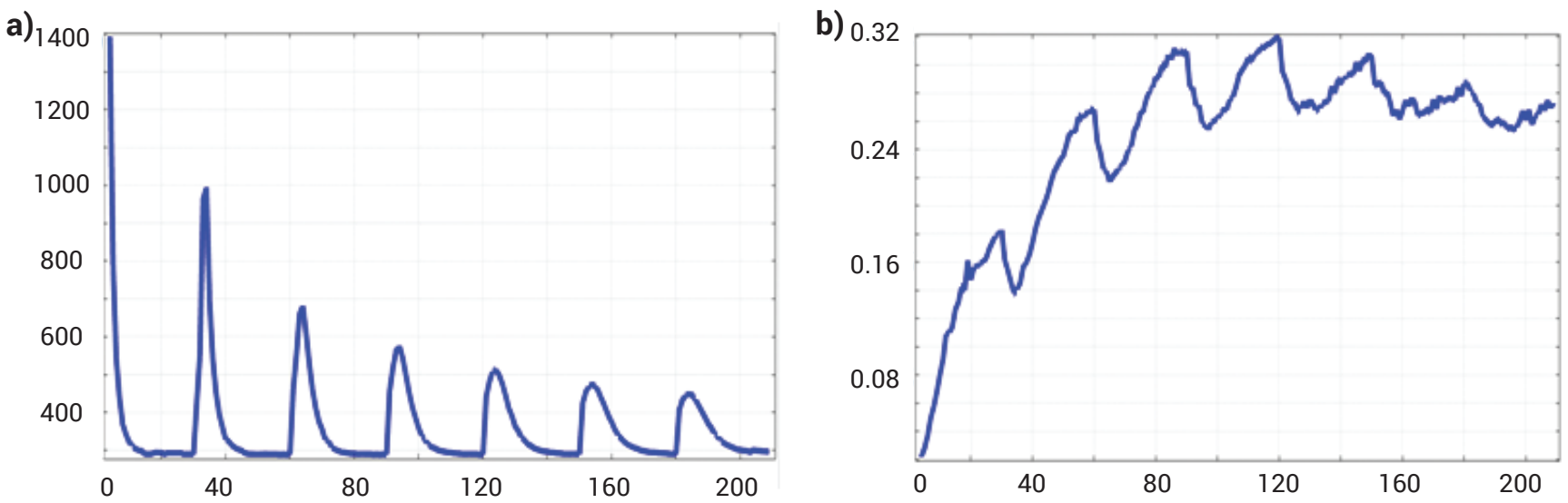

Fig. 4. Effect of deposition time of 09G2S steel additive layers on: a) thermal cycle, b) total substrate bending in central part Rys. 4. Wpływ czasu nanoszenia warstw addytywnych stali 09G2S na: a) cykl termiczny, b) całkowite zginanie podłoża w części środkowej

Analysis of the results shows (Fig. 5) that increase of preheating temperature allows 2.5 times reduction of the level of stresses at additive layer/substrate boundary and 2-3 times decrease of structure bending. The stress level reduces from $300-320 \mathrm{MPa}$ at $20^{\circ} \mathrm{C}$ (without heating) to $90-100 \mathrm{MPa}$ at $320^{\circ} \mathrm{C}$ preheating temperature (curve 3,4 in Fig. $5 \mathrm{a}$ ). Structure deformation decreases from $0.30-0.32 \mathrm{~mm}$ to $0.12-0.14 \mathrm{~mm}$. Further increase of substrate preheating temperature above $320^{\circ} \mathrm{C}$ does not affect the value of stresses and displacements of the additive structure.

One of the important tasks, which should be solved in modeling, was determination of the effect of thickness of a deposited layer on parameters of the additive structure.

On the one hand, efficiency of additive process is related to the amount of material deposited per unit of time. Based

a)

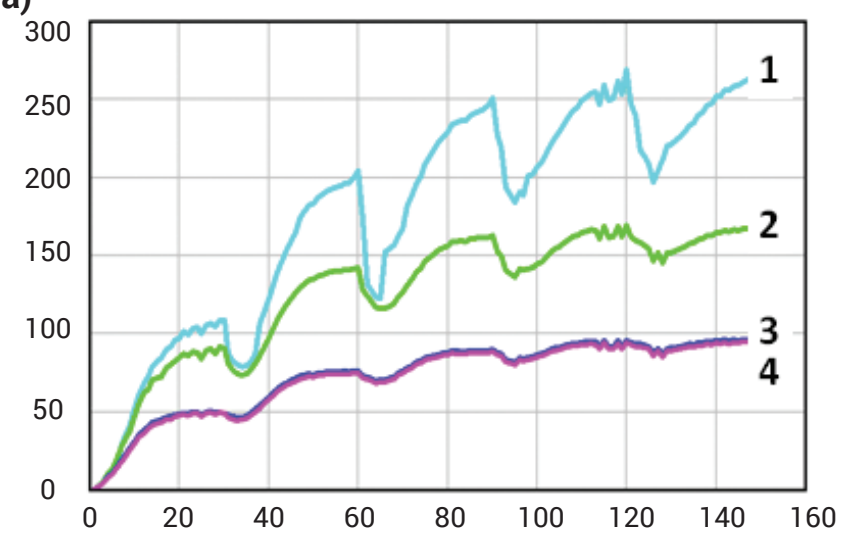

on this it is desirable to increase thickness of one layer pass. This can be reached either by increase of the amount of molten metal or reduction of process speed.

On the other hand, increase of amount of molten metal, which is limited by heat input of heat source and decrease of speed, will have noticeable effect on a liquid metal overheating value that has negative effect on product properties. During layer deposition it is desirable to develop a temperature mode close to stationary one in order to obtain uniform properties of the product on deposition height.

Therefore, the work determines effect of layer thickness on stress value at layer/substrate boundary, deformations and average temperature of the additive structure. The layer thickness during modelling was $0.5 \mathrm{~mm}, 1.0 \mathrm{~mm}$ and $5.0 \mathrm{~mm}$.

b)

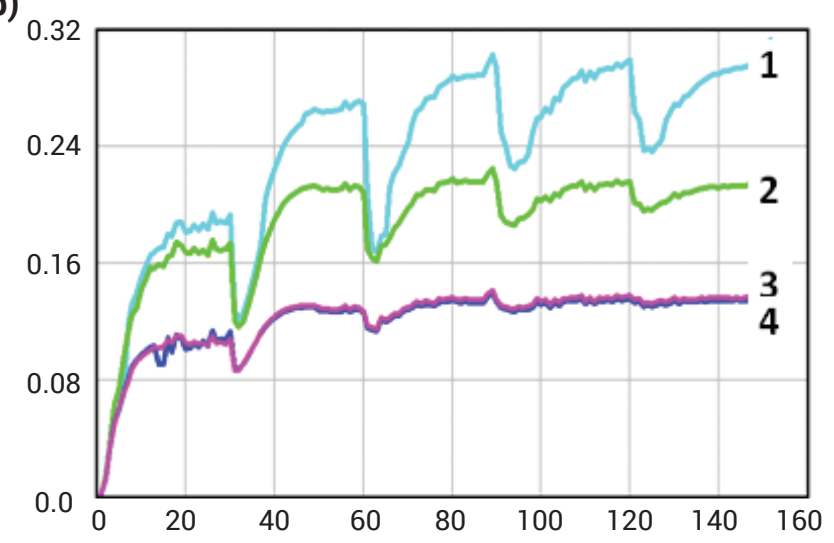

Fig. 5. Effect of temperature of substrate preheating on value of: a) stress at layer/substrate boundary, b) displacement. Temperature of preheating: $1-20{ }^{\circ} \mathrm{C} ; 2-120^{\circ} \mathrm{C} ; 3-320^{\circ} \mathrm{C} ; 4-420^{\circ} \mathrm{C}$

Rys. 5. Wpływ temperatury podgrzewania podkładu na wartość: a) naprężeń na granicy warstwy/podkładu, b) przemieszczenia. Temperatura podgrzewania wstępnego: $1-20^{\circ} \mathrm{C} ; 2-120^{\circ} \mathrm{C} ; 3-320^{\circ} \mathrm{C} ; 4-420^{\circ} \mathrm{C}$

a) 500

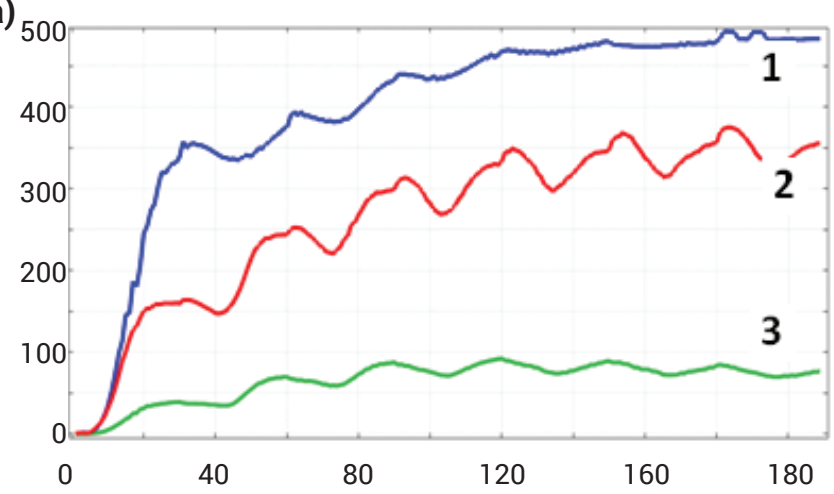

b)

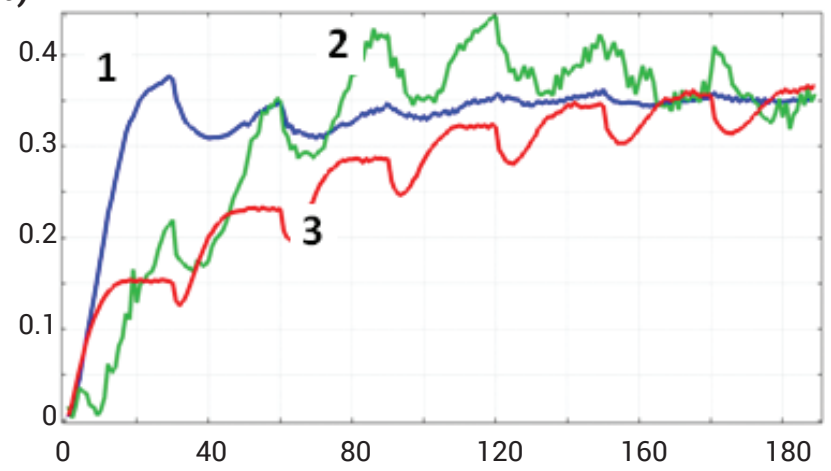

Fig. 6. Effect of layer thickness on value of stresses (a) and deformations (b) in additive structure $1-5.0 \mathrm{~mm}, 2-1.0 \mathrm{~mm}, 3-0.5 \mathrm{~mm}$ Rys. 6. Wpływ grubości warstwy na wartość naprężeń (a) i deformacji (b) w konstrukcji addytywnej $1-5.0 \mathrm{~mm}, 2-1.0 \mathrm{~mm}, 3-0.5 \mathrm{~mm}$ 
Group of authors showed [12] that the stationary temperature mode in the central part of tee profile is reached after the 8th layer deposition on the substrate.

It is determined that the stationary mode of additive deposition depends on deposit thickness. The stationary mode for thin layers $(0.5 \mathrm{~mm})$ is achieved after deposition of the third layer (curve 3, Fig. 6a). Whereas, for thicker layers $(1 \mathrm{~mm}, 5 \mathrm{~mm})$, it is reached after deposition of 6-7 layers (curves 1 and 2, Fig. 6a).

This peculiarity of stationary mode is associated with the above-mentioned difficulty of heat sink from the additive structure to the substrate.

Using the calculations of a model of elastic-plastic material behavior instead of a model of linear elastic material behavior allows determining formation of the deposited layers in cooling due to plastic deformation (Fig. 7). Calculations shows the narrowing of the substrate by $2.17 \mathrm{~mm}$ on length and on $0.5 \mathrm{~mm}$ height.

Further development of this work should concentrate more on physical phenomena, which are accompanied by additive deposition process.

Structural transformations can not be neglected in modeling the additive process of products made from steels with more complex chemical composition. On the one hand, it is related to heat emission in cooling that result in local temperature increase. And, on the other hand, transformation of austenite into bainite or martensite is accompanied with variation of properties of a layer being modeled and its noticeable change of volume. Formation of hardening

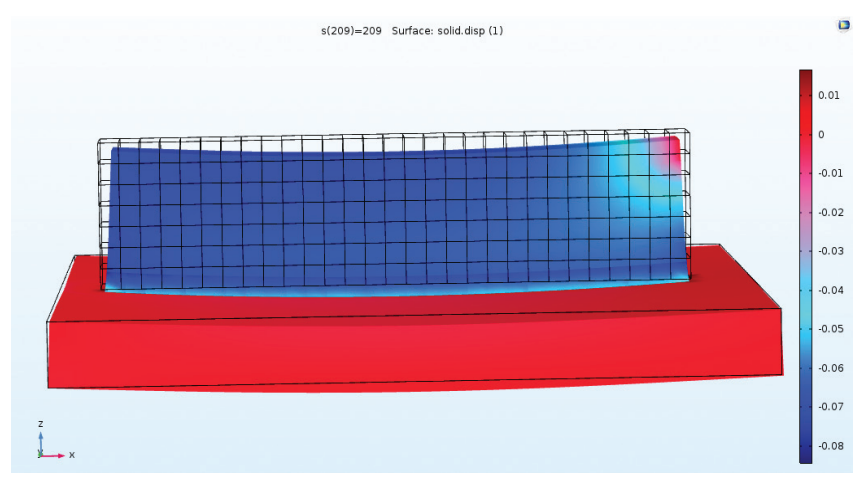

Fig. 7. Geometry of additive layers of steel 09G2S taking into account plastic deformations

Rys. 7. Geometria warstw addytywnych stali 09G2S z uwzględnieniem odkształceń plastycznych

(martensite) structures in the deposited layers can lead to their considerable deformation and even destruction.

As a result, two above mentioned differential equations for additive layers modeling should be completed by the structural transformation equations for austenite $\rightarrow$ ferrite, austenite $\rightarrow$ bainite and austenite $\rightarrow$ martensite.

The results of modeling of temperature fields, stresses and deformations can be used for solution of a practical problem on improvement of technological parameters of the additive process for formation of the workpieces of parts and structures.

\section{Conclusions}

1. The highest level of residual stresses and deformations is reached at the boundary of first layer and substrate and is $280 \div 320 \mathrm{MPa}$ in additive deposition of steel 09G2S on the substrate. Stresses between the deposited layers are significantly lower (up to $50 \mathrm{MPa}$ ).

2. It is determined that increase of number of deposited layers provokes gradual rise of the level of stresses at additive layer/substrate boundary and in time does not depend on number of the deposited layers. The stationary deposition mode is reached after 7-8 layers deposition.

3. Deposition of layers requires substrate preheat to temperatures not lower than $300 \div 320{ }^{\circ} \mathrm{C}$ for elimination of noticeable deformation of the additive structure.

4. Structural transformation equations should be introduced in the mathematical model for modeling the additive process of products of alloys (steels) with more complex chemical and structural composition.

\section{References}

[1] Zhukov V. V., Grigirenko G. M., Shapovalov V.A.: Additive manufacturing of metal products (Review), The Paton Welding Journal, No. 5-6, 2016, pp. 137-142.

[2] Akhonin S. V., Vrzhizhevsky E. L., Belous V. Yu.,Petrichenko I. K.: Electron beam 3D-deposition of titanium parts, The Paton Welding Journal, No. 5-6, 2016, pp. 130-133.

[3] Korzhik V. N., Khaskin V. Yu., Grinyuk A. A. et. al.: 3D-printing of metallic volumetric parts of complex shape based on welding plasma-arc technologies (Review), The Paton Welding Journal, No. 5-6, 2016, pp. 117-123.

[4] Kaufui V. Wong, Aldo Hernandez: A Review of Additive Manufacturing, International Scholarly Research Network - Mechanical Engineering, 2012, Vol. 2012, Article ID 208760, 10 pages, doi:10.5402/2012/208760.

[5] P. M. Rizwan Ali, C. R. Hara Theja, Syed Mahammad Syed Saheb, C.Yuvaraj: Review on Diverse Materials Applied For Additive Manufacturing, International Journal for Research in Applied Science \& Engineering Technology (IJRASET), Vol.3 Issue VII, July 2015, pp.16-20.

[6] D. Ding, Z. Pan, D. Cuiuri, H. Li: Wire-feed additive manufacturing of metal components: technologies, developments and future interests, International Journal of Advanced Manufacturing Technology, №81, 2015, pp. 465-481.
[7] V. A. Shapovalov, G. M. Grigorenko: Control of metal structure in process of solidification, Advances in electrometallurgy, No.2, 2015, pp. 51-54.

[8] V. A. Shapoovalov, G. M. Grigorenko: Suppression of liquation processes in large ingots, Advances in electrometallurgy, No.1, 2015, pp. 26-30.

[9] https://www.comsol.com

[10] V. A. Kostin, V. V. Zhukov Modeling of processes of production of metallic parts using additive technologies: Proceedings of the 8th International Conference, Mathematical modeling and information technologies in weIding and related processed. Edited by I. V. Krivtsun, September 19-23, Odessa, Ukraine.

[11] http://tehtab.ru/Guide/GuidePhysics/GuidePhysicsHeatAndTemperature/ConvectionHeatTransfer1/OverallHeatTransferCoefficients/

[12] O. V. Makhnenko, A. S. Milenin, E. O. Velikoivanenko, G. F. Rosynka et.al.: Modelling of temperature fields and stress-strain state of small 3D sample in its layer-by-layer forming using xBeam 3D Metal Printer, Proceedings of the 8th International Conference «Mathematical modeling and information technologies in welding and related processed. Edited by $\mathrm{I}$. V. Krivtsun, September 19-23, Odessa, Ukraine. 